\title{
Impact of Macroeconomic and Bank Specific Variables on Spread of Interest Rate: A Study of Listed Commercial Banks in Bangladesh
}

\author{
Md. Tanvirul Hoque ${ }^{1}$, JanifarAlam² ${ }^{2}$, Susmita Dev Burman ${ }^{2}$, and Quazi Nur Alam² \\ ${ }^{1}$ AVP and Head of Branch, The Premier Bank Ltd, Pallabi Branch, Dhaka, Bangladesh; ${ }^{2}$ Department of Business Studies, \\ University of Information Technology \& Sciences (UITS), Dhaka, Bangladesh.
}

*Correspondence: janifar.alam@uits.edu.bd (Janifar Alam, Assistant Professor, Department of Business Studies, UITS, Dhaka, Bangladesh).

\begin{abstract}
The Banking system of a country provides the lifeblood to the efficient and effective functioning of an economy. Therefore it is crucial to understand the lending and borrowing rates and hence the spread of interest rates in the banking and financial sector. The Spread of Interest rate is the difference between loan rates and the deposit rates of a bank. High interest rate reflected in the spread of a high-interest rate will immensely disrupt and cause adverse consequences in the whole economy. Both the spread of interest rate and the interest margin show that the intermediation cost is higher in Bangladesh. High-interest margins in a banking system are indicative of deep-rooted symptoms of inefficiency, absence of competition, nondiversification of income sources, and skewed development of money and capital market in favour of banks' lending and inflexibility of rate adjustments symmetrically in response to market changes. Moreover, a frequent financial scam in Bangladesh has added more troubles in the money market of Bangladesh. For example, Hallmark scam of almost 4000 crore taka of Sonali Bank, a financial scam of Abdul Mannan, CEO of BIFC, amounted around 950 crore taka, around 4500 crore taka scam of Janata bank and Agrani bank have made our money market and financial market susceptible to failure. These events have some direct or indirect impacts on interest rates. Hence, I have felt the importance of identifying the determinants of spread of interest rate. Understanding the determinants of the spread of interest rates would enable us to eliminate such unnecessary cost in financial intermediation, which would be the result in operational and administrative efficiency, resulting in financial viability, stability and economic growth. Therefore, we need to know the determinants of the spread of interest rates. Hence, I have been motivated to study the determinants of interest rate spread and their extent of impacts on interest rate spread.
\end{abstract}

Keywords: Interest rate spread, Macro-economic variable, Credit risk, Net income, GDP, and Inflation.

\section{INTRODUCTION:}

\subsection{Background of the study}

An efficient and vibrant commercial banking sector is a vital precondition for any market economy to be successful. Especially commercial banks provide an array of services to individuals and businesses covering almost all financial needs of individuals and businesses. Commercial banks financial services cover not only financing of foreign trade, domestic trade and industries, but also facilitate smooth functioning of the payment system in the economy. A stable financial system creates a favourable environment for depositors and investors that encourages efficient financial intermediation and the effective functioning of markets and hence promotes investments and economic growth. 


\subsection{Objective of the study}

To analyse the evolution and determinants of spread of interest rate in commercial banks operating in Bangladesh.

$>$ To understand how the spread of interest rate is influenced by bank characteristics, banking industry characteristics and macroeconomic variables.

\subsection{Scope of the study}

This report deals with the identification of the determinants of spread of interest rate. Interest rate spread varies from bank to bank. It depends on some bank specific variables, some macroeconomic variables. Whatever, in this report data of 11 years of all the listed banking organizations have been included to determine which factor actually have impacts on spread of interest rate. The results then can be applied to know why spread of interest rate in some banks is higher and vice versa. In some adverse situation of economic condition, the results can be used as a guide to set the spread of interest rate.

\section{Literature review}

Studies to find out the determinants of spread of interest rate have been focusing on some factors which include; (1) individual bank specific factors such as- liquidity position, total assets and current assets, the rate of non-performing loan, the size of the banks, the operating cost and net operating income; (2) Macroeconomic factors include Gross Domestic Product (GDP) index, inflation and policy rate. This is not that interest rate spread depends on these factors only. It may depend on some other factors such as quality of the bank management, efficiency of the banking operations etc. However, a brief review of empirical studies that were conducted previously to determine the determinants of the spread of interest rate is demonstrated below: Maureen Were and Joseph Wambua, (2013) have studied the determinant of spread of interest rate in Kenya. It is my base research paper to be used as a guideline during the preparation of my research.

Using the panel data analysis, Maureen Were and Joseph Wambua, (2013) found significant impacts of bank-specific variables (liquidity, credit risk, bank size, ROA, operating cost, net interest income as a part of total income) on the interest rate spread. Macro-economic variables such as GDP and inflation were not found to have significant impacts on interest rate spread. Policy rate was found to have positive relationship with interest rate spread but the significance was very weak. Gambarcorta, (2004) studies factors that explain cross-sectional differences in spread of interest rate of banks in Italy.

The study included both the micro and macroeconomic variables and the variables are operating cost, credit risk, interest rate volatility, loan demand and impact of monetary policy reflected by changes in policy rate. The study revealed that short term interest rate react less to monetary policy rate changes. In addition, the long term interest rate does not also change as banks don't feel to change long term interest rate frequently. Bank size has not been found to be an influential factor to determine interest rate spread. The study of Gambarcorta also found a positive relationship between spread of interest rate and GDP and inflation.

During the economic boom phase, the demand for loan increases where demand for deposits also increases at the same time which in turn compels the banks to increase the spread of interest rate. Operating cost and credit risk have a positive relationship with the spread of interest rate according to his study. Banks need to incur cost to analyse the loan portfolio and monitoring the performance of loan takers. The higher the cost the larger the spread of interest rate. The study also revealed that a tightening monetary policy that increases the interest rate compels the banks to increase the lending rate and thus the interest rate spread. Mannasoo, (2012) also studied the determinants of interest rate spread in Estonia. He divided the spread of interest rate into pure interest rate and the remaining part to be explained by the market structures, regulations and idiosyncratic factors of banking organizations. According to his study, money market volatility and bank risk attitude have impacts on the pure interest rate spread. Credit risk has been found to have minimal impacts on the interest rate spread. On the other hand, the higher bank liquidity has been found to cause of lower interest rate margins.

Grenade, (2007) conducted study to find out the determinants of spread of interest rate of commercial bank by using the annual panel data of commercial banks in the Eastern Caribbean Currency Union. The study model includes factors such as regulatory Variables (statutory minimum savings rate), market power, and non-performing loan ratio; operating cost 
depends on net operating income, liquidity risk and real GDP. According to the study, statutory minimum savings rate market power, credit risk; operating cost and GDP have a positive relationship with spread of interest rate.

Siddiqui, (2012) studied the determinants of spread of interest rate in Pakistan by using annual panel data of 22 commercial banks. The variables of the study include the market share, administrative expenses, liquidity risk, credit risk, net interest income as a share of total income, and return on average assets. The study has found significant positive relationship between spread of interest rate and credit risk, administrative cost and return on assets. There have been a few studies on this topic in Bangladesh. Mustafa K. Mujeri and Sayera Younus, (2009) have studied the determinants of spread of interest rate by using the profit maximization model that based on industrial organization approach. They have used panel data consist of 48 Banks from 2004 to 2008. The study revealed that, the higher noninterest income of a bank leads lowers the spread of interest rate. It also disclosed that interest rate is impacted significantly by reserve ratio, operating cost and market share of a bank. So, there is a space to work with some other variables to identify the determinants of spread of interest rate.

I have used variables such as credit risk, liquidity, bank size, operating cost, net interest income as a part of total income, ROA, GDP, inflation and policy rate. I hope this research will provide more clear in sights and more information about the determinants of spread of interest rate.

\section{METHODOLOGY:}

In this report both regression analysis and descryptive analysis have been conducted. Regression analysis has been conducted to assess the impacts of determinants of the spread of interest rate. Descriptive analysis has been conducted to show the summaries and basic features of spread of interest rate and other variables related to the spread of interest rate. Regression analysis has been undertaken by using panel data of 30 listed banking organizations from 2006 to 2017. Fixed and random effects model have been tested in this report. The basic assumptions of both fixed and random effect model are; the effects not explained by the explanatory variables are driven by; (1) individual time variant factors that include management quality of bans, efficiency of operations and technical distinctions among banks; (2) period individualinvariant factors. These factors seem to be same for all banks but fluctuate over time. Dependent and independent variable: Maureen Were and Joseph Wambua, (2013) have used some variables in their studies.

Therefore, I have selected these variables to work with. In this report the measured variable is the spread of interest rate and the independent variables include; Bank specific factors: Credit risk (CR), liquidity (LR), operating cost; net operating income after tax (OCNOI), net interest income as a part of total income (NIITI), bank size (LBS), and Return On Assets (ROA) are the bank-specific variables. Macro-economic factors: DGP, inflation (INF) rate are macro-economic variables. Monetary policy factor: Policy rate (PR) is the representation of monetary policy impact. The empirical model is;

$$
\mathrm{IRSit}=\mathrm{ai}+\mathrm{Xit} \beta+\mathrm{Zt} \gamma+\varepsilon \mathrm{it}
$$

Here, IRS it is the spread of interest rate for bank I at time $\mathrm{t}$ measured the difference between interest income and interest expenses; ai is the bank specific fixed effects represented by the unobserved variables; Xit $\beta$ is a vector of bank specific variable, $\mathrm{Zt} \gamma$ is a vector of time specific variables, and eit is the statistical error.

Total 3 models have been developed as; Model-1: Includes only bank-specific variables -

$\mathrm{INRS}=\mathrm{ai}+\mathrm{LR}+\mathrm{LBS}+\mathrm{CR}+\mathrm{NIITI}+\mathrm{OCNOI}+\mathrm{ROA}$

Model-2: Includes only bank-specific variables + macro-economic variables -

$$
\begin{aligned}
& \mathrm{INRS}=\mathrm{ai}+\mathrm{LR}+\mathrm{LBS}+\mathrm{CR}+\mathrm{NIITI}+\mathrm{OCNOI}+\mathrm{ROA} \\
& +\mathrm{GDP}+\mathrm{INF}
\end{aligned}
$$

Model-3: Includes only bank-specific variables + macro-economic variables + monetary policy variable -

$$
\begin{aligned}
& \mathrm{INRS}=\mathrm{ai}+\mathrm{LR}+\mathrm{LBS}+\mathrm{CR}+\mathrm{NIITI}+\mathrm{OCNOI}+\mathrm{ROA} \\
& +\mathrm{GDP}+\mathrm{INF}+\mathrm{PR}
\end{aligned}
$$

\section{Bank-specific variables}

Credit risk - The ratio of non-performing loan to total outstanding loan is taken as an indicator of credit risk. When bad debts increase at higher rate 
banks needs to reserve more provisions for bad debts which forces the banks to charge premium on interest of loans. As a result, spread of interest rate becomes higher.

Liquidity - Liquidity is measured as the proportion of bank's current assets to current liabilities. A bank with higher liquidity position has lower liquidity resulting no premium for liquidity risk. Paradoxically, a bank with shortage of liquidity needs to borrow funds a higher rate in emergency situations which compel the banks to charge premiums on loans resulting higher interest rate spread.

Operating cost - Operating cost are the expenses which are related to the bank total business expenses consists interest expenses and administration expenses. Banks incur cost to select the appropriate borrowers. The cost of monitoring the loans portfolio also increases the operating cost. Therefore, the higher the financial intermediation cost, the more likely banks would charge higher interest rate on loans which in turn increases the spread of interest rate.

Net interest income - Net interest income is the prime source of income of a bank. The profitability of a bank depends mostly on this item. Therefore, the more dependent a bank is on the net interest income for its higher profitability, the more likely that the bank will charge higher interest rate on loan thus causing the interest rate spread go higher.

Bank size - Bank size is measured as a log of total capital of the bank. A larger bank enjoys the benefit of economies of scale and advance technology which justifies that a larger bank would charge lower interest rate thus resulting in a lower interest rate spread. A larger bank is supposed to possess the control of market which implies that by exercising monopoly or oligopoly power bank can charge higher interest rate on loan thus causing higher interest rate spread.

\section{Descriptive and empirical analysis}

\subsection{Descriptive analysis}

Table 1: Bank-specific variables
Return on assets - Return on assets is measured as net income divided by the total assets. It is a strong indicator of profitability on total assets. A bank with high return on assets is more likely to charge higher interest on loans which increases the interest rate spread.

\section{Macroeconomic variables}

GDP - GDP represents the Gross Domestic Product of a country in a specific year. When the economy goes well, the demand for loan increases. So, the higher demand of loan raises up the rate of interest on loans. On the other hand, in a good economic condition the rate of loan default decreases which causes the rate of interest on loans go down. So, both negative and positive relationship of spread of interest rate with GDP is observed.

Inflation - Inflation is measured as percentage of price increase from year to year. Inflation is an element of total interest rate. So, when inflation rate increases, the interest rate also increases which causes the spread of interest rate increase.

Monetary Policy impact - Policy rate represents the monetary policy impacts on the interest rate spread. In a contractionary monetary policy situation, the interest rate goes up thus the spread of interest rate also goes up. On the other hand, in an expansionary monetary policy situation the interest rate goes down thus causing the spread of interest rate goes down.

\subsection{Sources of data}

The report is based on quantitative analysis. So, quantitative data is the first requirement to conduct the report. Quantitative data about bank-specific variable has been collected from the annual report of all listed banking organizations. The macroeconomic data has been collected from the website of Bangladesh bank (Alam, 2020). So, all data required to conduct this report are secondary data.

\begin{tabular}{|l|r|r|r|r|r|r|r|}
\hline & \multicolumn{1}{|c|}{ INRS } & \multicolumn{1}{c|}{ LR } & \multicolumn{1}{c|}{ LBS } & \multicolumn{1}{c|}{ CR } & \multicolumn{1}{c|}{ NIITI } & \multicolumn{1}{c|}{ OCNOI } & \multicolumn{1}{c|}{ ROA } \\
\hline Mean & $3.41 \%$ & $25.24 \%$ & 11.0261 & $7.08 \%$ & $244.11 \%$ & $270.29 \%$ & $0.96 \%$ \\
\hline Median & $3.34 \%$ & $24.86 \%$ & 11.09 & $3.90 \%$ & $194.51 \%$ & $185.11 \%$ & $1.13 \%$ \\
\hline Std. Dev. & 0.01401 & 0.05923 & 0.36017 & 0.26451 & 4.27406 & 7.93792 & 0.02011 \\
\hline
\end{tabular}




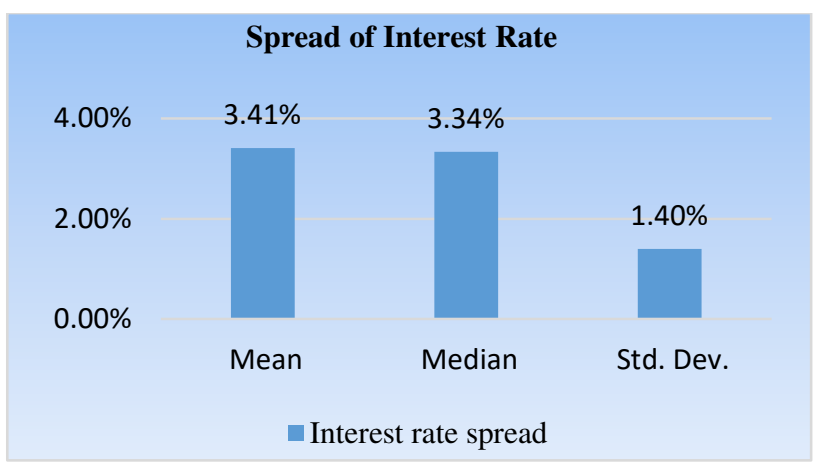

Fig 1: Average spread rate of interest.

During the period from 2006 to 2017 the average interest rate spread was $3.41 \%$ and the median was $3.34 \%$. The standard deviation of spread of interest rate was also low 0.01401 . The mean liquidity position was $25.24 \%$. The average non-performing loan as a percentage of total outstanding loans termed as credit risk is $7.08 \%$. The average net interest income as a part of total income was $244.11 \%$. The average operating cost as a portion of net income is $270.29 \%$. The average Return on Assets (ROA) was $0.96 \%$ (Fig 2).

During the period from 2006 to 2017 the average GDP was $6.36 \%$. The average inflation rate was
$7.49 \%$ and the average bank rate was $7.31 \%$. The standard deviation of GDP was 0.006237. The standard deviation of inflation was 0.015013 and the standard deviation of policy rate was 0.012439 (Fig 2).

Table 2: Macro-economic and monetary policy variables.

\begin{tabular}{|l|c|c|c|}
\hline & GDP & INF & PR \\
\hline Mean & $6.36 \%$ & $7.49 \%$ & $7.31 \%$ \\
\hline Median & $6.49 \%$ & $7.18 \%$ & $7.50 \%$ \\
\hline Std. Dev. & 0.006237 & 0.015013 & 0.012439 \\
\hline
\end{tabular}

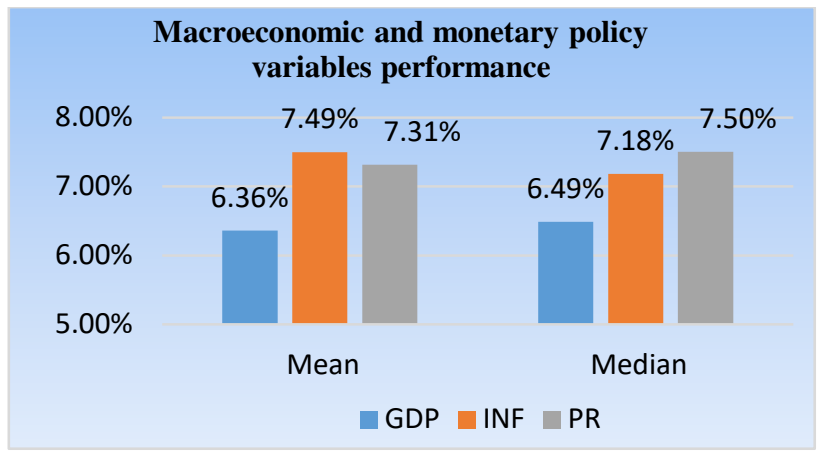

Fig 2: Macroeconomic and monetary policy variables performance.

\subsection{Empirical analysis}

\begin{tabular}{|l|l|l|l|l|l|l|}
\hline Variable & \multicolumn{3}{l}{ Column A } & Column B & \multicolumn{2}{l|}{ Column C } \\
\cline { 2 - 7 } & Coefficients & p-value & Coefficients & p-value & Coefficients & p-value \\
\hline C & -0.024036 & 0.5484 & 0.008195 & 0.6993 & 0.018132 & 0.3762 \\
\hline LR & -0.021997 & 0.6178 & 0.001716 & 0.8749 & -0.015575 & 0.1544 \\
\hline LBS & 0.005312 & 0.1362 & 0.001745 & 0.3521 & 0.001421 & 0.4186 \\
\hline CR & 0.000876 & 0.0793 & 0.002969 & 0.2105 & 0.001631 & 0.3518 \\
\hline NIITI & 0.00235 & 0 & 0.003904 & 0.00000 & 0.002449 & 0.00000 \\
\hline OCNOI & -0.001284 & 0 & -0.002087 & 0.00000 & -0.00134 & 0.00000 \\
\hline ROA & 0.287678 & 0 & 0.268244 & 0.00000 & 0.281108 & 0.0575 \\
\hline GDP & & & -0.177999 & 0.0758 & -0.133099 & 0.0575 \\
\hline INF & & & 0.14484 & 0.0006 & 0.167815 & 0.000000 \\
\hline PR & & & & & -0.069433 & 0.06420 \\
\hline No. of observations & 360 & 0.740645 & 360 & & 360 & \\
\hline R-squared & & 0.378449 & & 0.728855 & \\
\hline
\end{tabular}

Fixed effect model and random effect model has been conducted to produce panel data results in this report. Two tables has been developed for random effect model and fixed effect model. In the fixed effect table, the column A contains the coefficients

UniversePG I www.universepg.com and t-values of only bank-specific variables, column B contains bank-specific variables and macroeconomic variables, column $\mathrm{C}$ contains bank-specific, macro and policy rate variables. For robustness, heteroscedasticity across banks is conducted by 
using cross-section weights, thus leading to robust standard errors. The redundant fixed effects test and the Hausman test are used to determine the suitability of fixed effects model over random effects model. Hausman test has been undertaken to determine which model is valid. The Chi-square statistics is $<0.05$ which indicates that fixed effect is valid. So, the null hypothesis is rejected at $5 \%$ level of significance.

The empirical results reveal that all the explanatory variables show the expected sign except operating cost as a part of net income and policy rate. The coefficient of net interest income as a portion of total income is 0.002449 . It also reveals a positive relationship. It outlines that the more a bank is dependent on the interest income for its profitability, the higher the spread of interest rate. The p-value is 0.000 and the t-value is 7.134406 which are greater than 2 and the relationship is significant at 5\%level of significance. The coefficient of operating cost as a component of net income is -0.00134 . It reveals a negative relat-ionship with interest rate spread. The p-value is 0.000 and the t-value is -7.386633 which far less than 2 are. The t-statistics indicates the in significance of the relationship. The coefficient of ROA is 0.281108 . It indicates a positive relationship with the interest rate spread. To earn a higher return the bank must raise the interest rate spread. So, the positive relationship between ROA and spread of interest rate is valid. The p-value is 0.000 and the tvalue is 9.829989 which is much higher than 2 and the relationship is significant at $1 \%$ level of significance.

Among the macroeconomic variables, the coefficient of GDP is -0.133099 which reveals a negative relationship with interest rate spread. The reason behind the negative relationship is that when economic activity increases, the profitability of organizations also increases. High profitability refrain organizations from being default on loan and makes able to make loan and interest payment regularly. As a result of fewer defaults on loan, banks need not charge credit risk premium on interest rate. So, when GDP growth rate is higher, spread of interest rate is lower. Though the p-value is 0.0575 and the t-value is less than 2 the relationship is significant at $5 \%$ level of significance. The coefficient of inflation is 0.167815 . It also reveals a positive relationship with interest rate spread. The interest rate is measured by adding inflation with the real interest rate. So, when inflation rises, interest rate also rises. As a result, interest rate spread rises. So, the positive relationship is valid. The $\mathrm{p}$-value is 0.000 and the $\mathrm{t}$ - value is 5.689362 which are greater than 2 and the relationship is significant at $1 \%$ significance level. The coefficient of policy rate is -0.069433 which reveals a negative relationship with interest rate spread. Generally, when policy rate increases crate of interest on loans also increases. But this may not be always true. In another sense when interest rate rises, demand for loan decreases. In such situation a banking organization with high liquidity position faces troubles as unnecessary cash remains idle just losing the profitability. So, banks find solution just making the rate of interest on loans lower which results in lower interest rate spread. So, both positive and negative relation may exist. The $\mathrm{p}$-value is 0.06420 and the t-value is less than 2 but the relationship is significant at $10 \%$ level of significance. In the fixed effect the coefficient of liquidity position is -0.015575 . It reveals a negative relationship with interest rate spread. That is when a bank is in good liquidity position, it does not charge premium on rate of interest on loan thus making the spread of interest rate higher. So, when liquidity position is high, spread of interest rate is low. But the relationship is insignificant as t-value -1.42 is less than 2 . The p-value is 0.1544 The relationship is also insignificant at $10 \%$ significance level.

The coefficient of bank size is 0.001421 . It reveals a positive relationship with interest rate spread. The higher the bank size leads higher the spread of interest rate. Larger bank gets the control of larger market share and even the monopolistic or oligopolistic market power which induce them to charge higher interest rate on loans. However, the pvalue is 0.4186 the $t$-value 0.809963 is positive but less than 2 and the relationship is insignificant at $10 \%$ significance level. The coefficient of credit risk is 0.001631 . It reveals a positive relationship with interest rate spread. When a bank faces high level of credit risk, it charges credit risk premium on interest rate on loans which makes the spread of interest rate larger. So, the more the credit risk, the higher the spread of interest rate. However, the p-value is 0.3518 and the t-value is less than 2 and the relationship is insignificant at $10 \%$ significance level. 


\section{FINDINGS AND DISCUSSION:}

Operating cost as a portion of net operating income has a negative relationship with spread of interest rate. This result varies with the findings of previous studies such as the study of Gambarcorta, (2004). He found a positive relationship between the operating cost and spread of interest rate. However, this result is insignificant as the t-value is far less than 2. ROA has a positive relationship with interest rate spread. This result is similar with the findings of Sidiqqui, (2012). He found an effect on higher profitability behaviour on the interest rate spread.

DGP and inflation has negative and positive relationship resp-ectively with interest rate spread. This result is consistent with the findings of Gambarcorta, (2004). Those findings reveal that DGP can impact the spread of interest rate both positively and negatively. Gambarcorta, (2004) also found that as inflation increases, the interest rate also increases. Policy rate has a negative relationship with interest rate spread. This result is not consistent with previous results. But the t-value of this relationship is less than 2 and this relationship is insignificant at $5 \%$ level of significance.

The result is consistent in some extent to the findings of Gambarcorta, (2004). He said that both short term and long-term interest rate is insensitive to monetary policy stance. Sometimes one reason may work behind the negative relationship that decrease of loan demand compels the banks to decrease the interest rate and thus reducing the spread of interest rate. There is a negative relationship between liquidity position and interest rate spread. This result is consistent with the findings of Mannasoo, (2012). His study revealed a negative relationship between liquidity position of a bank and the interest rate spread. There is a positive relationship between bank size and spread of interest rate. This result is congruent with the findings of Allen, (1988). He concluded that banks' monopoly power has a positive impact on the interest rate spread. A positive relationship exists between credit risk and interest rate spread. This result is compliant with the studies of Sidiqqui, (2012). Sidiqqui also found a positive relationship between credit risk and spread of interest rate in commercial banks of Malawi and Pakistan. This result is also similar with the findings of Gambarcorta, (2004). This result is also similar with the findings of Mannasoo, (2012) who found a significant positive relationship between credit risk and spread of interest rate. Grenade, (2007) found a positive relationship between credit risk and interest rate spread. Net interest income as a part of total income has a positive relationship with spread of interest rate. This result is consistent with the findings of Folawewol and Tennant conducted in Sharan African countries.

So, the regression equation according to the fixed effect is -

\section{Model-1}

INRS $=0.018131-0.015574 * \mathrm{LR}+0.001420 * \mathrm{LBS}$ $+0.001631 * \mathrm{CR}+0.00244 * \mathrm{NIITI}-0.00133 *$ OCNOI $+0.281107 *$ ROA $-0.133098 *$ GDP + $0.167815 * \mathrm{INF}-0.069433 * \mathrm{PR}+\varepsilon_{\mathrm{it}}$

The value of R-square for this equation is 0.728855 . It means that $72 \%$ variation in the dependent variable is explained by the independent variables. Constant is 0.018131 . This means that interest rate spread will be 0.018131 irrespective of independent variables. There are some unobserved variables such as quality of management, use of most advanced technology which has impacts on the variation of dependent variable.

\section{Model-2}

INRS $=0.008195-0.001716 * \mathrm{LR}+0.001745 *$ $\mathrm{LBS}+0.002969 * \mathrm{CR}+0.003904 *$ NIITI $0.002087 *$ OCNOI $+0.268244 *$ ROA -0.177999

$*$ GDP $+0.14484 *$ INF $+\varepsilon_{\text {it }}$

The value of R-square for this equation is 0.378449 . It means that of $37.84 \%$ variability exist in the dependent variable and explained by the independent variables. Constant is 0.008195 . This means that interest rate spread will be 0.008195 irrespective of independent variables. There are some unobserved variables such as quality of management, use of most advanced technology which has impacts on the variation of dependent variable. It is apparent here that when we exclude policy rate from the independent variables, the constant decreases and the coefficients of independent variables increases except inflation.

\section{Model-3}

INRS $=-0.024036-0.021997 * \mathrm{LR}+0.005312 *$

LBS + $0.000876 * \mathrm{CR}+0.00235 *$ NIITI -0.001284

$*$ OCNOI $+0.287678 * \mathrm{ROA}+\varepsilon_{\mathrm{it}}$ 
The value of R-square for this equation is 0.740645 . It means that $74 \%$ of the variability of spread of interest is accounted for by the variables in the model. Constant is -0.024036 . This means that interest rate spread will be - 0.024036irrespective of independent variables. It is apparent here that when we exclude macro-economic and policy rate variables, the impacts of bank-specific variables on the dependent variables increases.

\section{CONCLUSION:}

From the Fixed Effect, It is seen that credit risk, bank size, net interest rate income ratio, ROA is positively related to the spread of interest rate. But only net interest income, ROA has significant relationship at $10 \%$ level of significance. This result is similar with the previous studies. In contrast, liquidity position, operating cost ratio GDP and policy rate is negatively related to interest rate spread. In this respect operating cost, GDP and policy rate has significant relationship with interest rate spread. Among them liquidity position, GDP is consistent with previous studies. Operating cost and policy rate are inconsistent with previous result but insignificant at t-values and at 5\% level of significance.

\section{ACKNOWLEDGEMENT:}

The authors would like to thank all co-authors for the valuable suggestions in writing this article and also all kind of support.

\section{CONFLICTS OF INTEREST:}

The authors declare no conflict of interest.

\section{REFERENCES:}

1) Alam QN. (2020). Impacts of macroeconomic variables on the stock market returns of South Asian region, Can. J. Bus. Inf. Stud., 2(2), 24-34. https://doi.org/10.34104/cjbis.020.24034
2) Allen, L. (1988). The Determinants of Bank Interest Margins: A Note. The Journal of Financial and Quantitative Analysis, 23(2), p.231. https://doi.org/10.2307/2330883

3) Gambacorta, L. (2004). How banks set interest Rate? National Bureau of Economic Research, Working Paper 10295, Cambridge, MA 02138, Pp. 1-39.

https://core.ac.uk/download/pdf/6819843.pdf

4) Grenade, K. H. I. (2007). Determinants of Commercial Banks Interest Rate Spreads: Some Empirical Evidence from the Eastern Caribbean Currency Union. Eastern Caribbean Central Bank Staff, Research Paper No. WP/ 07/01.

5) Mannasoo, K. (2012). Determinants of Bank Interest Spread in Estonia, EESTIPANK, Working Paper No. 1/2012.

https://www.researchgate.net/publication/3228 $\underline{31781}$

6) Maureen Were, and Joseph Wambua, (2013). Assessing the determinants of interest rate spread of commercial banks in Kenya: An empirical investigation, $K B A$ centre for research on financial market and policy. Working paper series - 4, Pp. 1-28. https://www.kba.co.ke/downloads/Working_P aper_WPS_04_12\%5B2\%5D.pdf

7) Mustafa K. Mujeri, and Sayera Younus, (2009). An Analysis of Interest Rate Spread in the Banking Sector in Bangladesh. The Bangladesh Development Studies, 32(4): 134.

https://ideas.repec.org/a/ris/badest/0487.html

8) Siddiqui M. A. (2012). Towards Determination of Interest Spread of Commercial Banks: Empirical Evidences from Pakistan. African Journal of Business Management, 6(5), pp. 1851-1862.

https://doi.org/10.5897/AJBM10.929 


\section{APPENDIX:}

\section{Dependent and independent variables}

\begin{tabular}{|c|c|c|c|c|c|c|c|c|c|c|}
\hline \multirow{2}{*}{\multicolumn{2}{|c|}{ Bank Name Year }} & \multirow[b]{2}{*}{ INRS } & \multicolumn{5}{|c|}{ Bank Specific Variable } & \multicolumn{3}{|c|}{ Macroeconomic vairable } \\
\hline & & & Liquidity risk & Retun on average asset & Credit risk Bank size & Operating cost & Net interest & GDP & Inflation P & olicy rate \\
\hline ABBANK & 2006 & 615504605 & 0.235863711 & 0.011089679 & $4.01 \% 47989337222$ & 3.644362033 & 1.156558424 & $6.67 \%$ & $7.16 \%$ & $8.50 \%$ \\
\hline ABBANK & 2007 & 1439281171 & 1. 0.245770573 & 0.02995276 & $4.31 \% 63549864405$ & 0.699391491 & 0.756125992 & $7.06 \%$ & $7.20 \%$ & $8.50 \%$ \\
\hline ABBANK & 2008 & 2020610153 & 3 0.215761952 & 0.027703001 & $2.99 \% 84190890927$ & 0.809265494 & 0.866344466 & $6.01 \%$ & $9.94 \%$ & $8.50 \%$ \\
\hline ABBANK & 2009 & 2964367189 & 0.231747686 & 0.031908574 & $2.75 \% 1.07093 \mathrm{E}+11$ & 0.732957491 & 0.867488032 & $5.05 \%$ & $6.66 \%$ & $8.75 \%$ \\
\hline ABBANK & 2010 & 4084937222 & 0.200738836 & 0.029771675 & $2.11 \% \quad 1.34004 E+11$ & 0.945443167 & 1.023916975 & $5.57 \%$ & $7.31 \%$ & $4.50 \%$ \\
\hline ABBANK & 2011 & 3323316259 & 0.253921411 & 0.009004807 & $2.82 \% \quad 1.54405 \mathrm{E}+11$ & 2.676876212 & 2.390212884 & $6.46 \%$ & $8.80 \%$ & $5.50 \%$ \\
\hline ABBANK & 2012 & 3810633195 & 0.271869698 & 0.008328575 & $3.32 \% \quad 1.75517 \mathrm{E}+11$ & 2.940926487 & 2.606792768 & $6.52 \%$ & $10.62 \%$ & $7.75 \%$ \\
\hline ABBANK & 2013 & 4083924785 & 0.228630785 & 0.005236942 & $3.37 \% \quad 2.09749 \mathrm{E}+11$ & 4.166636666 & 3.717924467 & $6.01 \%$ & $7.70 \%$ & $7.75 \%$ \\
\hline ABBANK & 2014 & 6458942934 & 0.220342143 & 0.006050757 & $3.86 \% \quad 2.48164 E+11$ & 3.599483037 & 4.301424306 & $6.06 \%$ & $6.99 \%$ & $7.25 \%$ \\
\hline ABBANK & 2015 & 4620049436 & $5 \quad 0.208378674$ & 0.005078826 & $3.06 \% 2.86939 \mathrm{E}+11$ & 3.919927452 & 3.170253379 & $6.55 \%$ & $6.16 \%$ & $7.25 \%$ \\
\hline ABBANK & 2016 & 3310848438 & B $\quad 0.250836152$ & 0.004757064 & $3.01 \% 3.17169 \mathrm{E}+11$ & 3.990693308 & 2.194369995 & $7.10 \%$ & $5.68 \%$ & $6.75 \%$ \\
\hline ABBANK & 2017 & 3158006462 & 0.16121133 & 0.000128776 & $2.97 \% 3.17098 E+11$ & 147.4463128 & 77.33656884 & $7.24 \%$ & $5.70 \%$ & $6.75 \%$ \\
\hline ALARABANK & 2006 & 881682692 & 0.130282549 & 0.021996196 & $3.72 \% 21368168142$ & 0.814858027 & 1.87584716 & $6.67 \%$ & $7.16 \%$ & $8.50 \%$ \\
\hline ALARABANK & 2007 & 614518980 & 0.184570837 & 0.011507204 & $3.68 \% 30182323406$ & 1.643469606 & 1.769346148 & $7.06 \%$ & $7.20 \%$ & $8.50 \%$ \\
\hline ALARABANK & 2008 & 1281678168 & 0.182399638 & 0.017065091 & $2.75 \% 39158437848$ & 0.955790403 & 1.917984227 & $6.01 \%$ & $9.94 \%$ & $8.50 \%$ \\
\hline ALARABANK & 2009 & 1337197611 & 1. 0.184145569 & 0.017705323 & $1.68 \% 48515787384$ & 1.05760004 & 1.556713325 & $5.05 \%$ & $6.66 \%$ & $8.75 \%$ \\
\hline ALARABANK & 2010 & 1172939817 & 0.208482358 & 0.026471816 & $1.14 \% 74005006188$ & 0.678195168 & 0.598729835 & $5.57 \%$ & $7.31 \%$ & $4.50 \%$ \\
\hline ALARABANK & 2011 & 4014894318 & 0.20735538 & 0.020593696 & $0.95 \% 1.06768 \mathrm{E}+11$ & 0.700256065 & 1.825988219 & $6.46 \%$ & $8.80 \%$ & $5.50 \%$ \\
\hline ALARABANK & 2012 & 5288123832 & 0.213024819 & 0.013028345 & $1.63 \% \quad 1.4932 \mathrm{E}+11$ & 1.144527715 & 2.718274627 & $6.52 \%$ & $10.62 \%$ & $7.75 \%$ \\
\hline ALARABANK & 2013 & 5858613435 & 0.201060235 & 0.013147722 & $2.77 \% \quad 1.73162 E+11$ & 1.171505944 & 2.57331329 & $6.01 \%$ & $7.70 \%$ & $7.75 \%$ \\
\hline
\end{tabular}

\section{Fixed Effect Model}

\begin{tabular}{|c|c|c|c|c|}
\hline Dependent Variable & & & & \\
\hline Method: Panel Least & & & & \\
\hline Date: 08/06/18 Tim & & & & \\
\hline Sample: 20062017 & & & & \\
\hline Periods included: 12 & & & & \\
\hline Cross-sections inclue & & & & \\
\hline Total panel (balance & & & & \\
\hline Variable & Coefficient & Std. Error & t-Statistic & Prob. \\
\hline LR & -0.015575 & 0.01091 & -1.427578 & 0.1544 \\
\hline LBS & 0.001421 & 0.001754 & 0.809963 & 0.4186 \\
\hline INF & 0.167815 & 0.029496 & 5.689362 & 0.000000 \\
\hline GDP & -0.133099 & 0.069827 & -1.906125 & 0.0575 \\
\hline CR & 0.001631 & 0.001749 & 0.932455 & 0.3518 \\
\hline NIITI & 0.002449 & 0.000343 & 7.134406 & 0.00000 \\
\hline OCNOI & -0.00134 & 0.000181 & -7.386633 & 0.00000 \\
\hline PR & -0.069433 & 0.037381 & -1.857452 & 0.06420 \\
\hline ROA & 0.281108 & 0.028597 & 9.829989 & O \\
\hline C & 0.018132 & 0.020463 & 0.886086 & 0.3762 \\
\hline & Effects Specification & & & \\
\hline & & & & \\
\hline Cross-section fixed & & & & \\
\hline R-squared & 0.728855 & Mean dependent var & & 0.034061 \\
\hline Adjusted R-squared & 0.696757 & S.D. dependent var & & 0.014011 \\
\hline S.E. of regression & 0.007715 & Akaike info criterion & & -6.789229 \\
\hline Sum squared resid & 0.019108 & Schwarz criterion & & -6.368234 \\
\hline Log likelihood & 1261.061 & Hannan-Quinn criter. & & -6.621833 \\
\hline F-statistic & 22.70705 & Durbin-Watson stat & & 1.281306 \\
\hline Prob(F-statistic) & 0.000000 & & & \\
\hline
\end{tabular}

Citation: Hoque MT, Alam J, Burman SD, and Alam QN. (2020). Impact of macroeconomic and bank specific variables on spread of interest rate: a study of listed commercial banks in Bangladesh, Can. J. Bus. Inf. Stud., 2(6), 148-156. https://doi.org/10.34104/cjbis.020.01480156 @ 